\title{
PELATIHAN LITERASI MENULIS ESAI BAGI ANGKATAN MUDA MUHAMMADIYAH KOTA PAREPARE
}

\section{ESAI WRITING LITERATION TRAINING FOR YOUTH FORCE MUHAMMADIYAH KOTA PAREPARE}

\author{
${ }^{1)}$ Yadi Arodhiskara, ${ }^{2}$ Patahuddin, ${ }^{3)}$ Suherman, ${ }^{4}$ Buhaerah, ${ }^{5}$ Asram A.T. Jadda \\ ${ }^{1)}$ Program Studi Akuntansi, ${ }^{2}$ Program Studi Pendidikan Bahasa Inggris, ${ }^{3)}$ Program Studi Agroteknologi, \\ ${ }^{4)}$ Program Studi Pendidikan Matematika, ${ }^{5)}$ Program Studi Ilmu Hukum \\ ${ }^{1,2,3,5)}$ Universitas Muhamamdiyah Parepare \\ Jend. Ahmad Yani No.Km. 6, Bukit Harapan, Soreang, Kota Pare-Pare, Sulawesi Selatan \\ ${ }^{4)}$ Institut Agama Islam Negeri Parepare \\ Jl. Amal Bhakti No.8, Bukit Harapan, Soreang, Parepare, Sulawesi Selatan 91131
}

Email: suherman.umpar@ymail.com

\begin{abstract}
ABSTRAK
Lemahnya pemahaman tentang karya tulis, misalnya esai dan karya ilmiah lainnya pada Angkatan Muda Muhammadiyah (AMM) di Kota Parepare merupakan salah satu parameter kurangnya karya cipta AMM Kota Parepare. Sebagai organisasi kepemudaan, Angkatan Muda Muhammadiyah (AMM) bertanggung-jawab untuk mewujudkan terciptanya Kader Bangsa, Kader Ummat dan Kader Persyarikatan yang memiliki wawasan intelektual dan berkompeten. Oleh kerana itu, kegiatan ini bertujuan untuk mewujudkan dan meningkatkan kesadaran terhadap budaya literasi serta menghasilkan karya tulis. Kegiatan dilaksanakan di ruangan pertemuan Sekolah Menengah Kejuruan Muhammadiyah (SMK) Kota Parepare (Sulawesi Selatan). Metode yang digunakan adalah ceramah, diskusi dan pelatihan/workshop. Metode ceramah dilakukan untuk memberikan wawasan pentingnya literasi. Diskusi dilakukan untuk mendalami permasalahan peserta.Pelatihan dilakukan untuk mengajarkan dan membimbing secara teknis membuat karya tulis esai atau karya ilmiah lainnya. Hasil kegiatan diperoleh 15 naskah esai yang layak dipublikasikan. Publikasi dilakukan dengan melibatkan penerbit UMPAR Press dengan judul buku "Kembali kepada Muhammadiyah".
\end{abstract}

Kata kunci: Literasi; Esai; Karya Tulis; Pelatihan

\begin{abstract}
Weak understanding of written works, for example, essays and other scientific works on the Muhammadiyah Youth Force (AMM) in the City of Parepare, is one of the parameters of the lack of AMM Parepare's copyrighted works. As a youth organization, the Muhammadiyah Youth Force (AMM) is responsible for realizing the creation of the National Cadre, the Ummat Cadre, and the Persyarikatan Cadre, who have intellectual and competent insight. Therefore, this activity aims to realize and increase awareness of literacy culture and produce written works. The action was held in the meeting room of the Parepare City Muhammadiyah Vocational High School (SMK) (South Sulawesi). The method used is lectures, discussions, and training/workshops. The lecture method was conducted to provide insight into the importance of literacy, discussions are held to explore the participants' problems and training is done to teach and guide technically writing essays or other scientific papers. The results of the activity obtained 15 articles that are worth publishing. The publication is carried out by involving UMPAR Press publishers with the title of the book "Back to Muhammadiyah."
\end{abstract}

Keywords: Literacy; Essay; Papers; Training

Submitted : 29 Januari 2019 Revision : 1 November 2019 Accepted : 17 Februari 2020 


\section{PENDAHULUAN}

Fenomena saat ini yang menunjukkan adanya dampak globalisasi teknologi mempengaruhi perilaku literasi pada remaja. Remaja cenderung menggunakan waktu yang tidak efektif (Junia, et al,, 2019). Kecenderungan remaja terhadap gadget sangat tinggi sekedar mengikuti trend yang ada saat ini. Hasil penelitian menunjukkan bahwa mereka menggunakan gadget lebih dari 11 jam perhari dengan tujuan untuk browsing dan paling banyak digunakan untuk bermain game online (Manumpil,et al., 2015).Selain itu juga digunakan untuk mengakses berbagai media sosial yang ada seperti instagram, path, facebook, twitter, whatsapp dan lainnya (Mulyati \& Frieda, 2019).

Penggunaan gadget (khususnya HP dan komputer) sebagai akibat perkembangan teknologi mendorong terjadinya keterasingan sosial dan memberi dampak perilaku individualistis serta mendorong ketidakpedulian sesama masyarakat. Daniel (2006) menyebut gejala tersebut sebagai social insulation atau social autism. Dampak dari social autism cenderung melahirkan konflik/pertentangan sosial di masyarakat, seperti konflik antar pemuda, antar kampung, antar desa, antar suku, dan antar golongan tertentu. Konflik juga sering terjadi diantara remaja di lembaga pendidikan, yaitu konflik antar pelajar dan antar mahasiswa (Maftuh, 2010).

Adanya konflik pada kalangan pelajar, mahasiswa atau pemuda pada umumnya menunjukkan kurangnya kemampuan untuk menciptakan kegiatan-kegiatan yang bermanfaat untuk mengisi rutinitas mereka. Salah satu pencetusnya adalah lemahnya budaya literasi (pemahaman) sehingga pemahamannya kurang dalam menanggapi berita bohong (hoax).

Permasalahan rendahnya minat membaca saat ini masih menjadi topik yang cukup aktual, khususnya pada remaja. Tema ini sering menjadi pembahasan menarik di setiap pertemuan/diskusi ilmiah para pemerhati/pakar yang peduli terhadap perkembangan minat baca di Indonesia. Namun hingga kini belum menghasilkan rekomendasi yang tepat dan signifikan dalam perkembangan minat baca masyarakat.
Budaya membaca masyarakat yang tinggi dapat diindikasikan sebagai karakter negara maju. Tumbuh kembangnya minat baca masyarakat, akan bermuara dalam mewujudkan kecerdaasan dan kemajuan bangsa. Hasil riset telah menekankan bahwa tersedianya jumlah perpustakaan dan koran bahkan ketersediaan komputer suatu negara mencirikan karakter sikap masyarakat yang terpelajar.

Budaya baca saat ini cukup memprihatinkan. Berdasarkan studi Central Connecticut State Univesity (CCSU) membuktikan bahwa Indonesia menduduki peringkat ke-60 dari 61 negara mengenai literasi (Akdiana, 2017). Peringkat tersebut menjelaskan suatu negara bukan berdasar seberapa besar kemampuan rakyat dalam membaca melainkan perilaku literasi (pemahaman) rakyat serta ketersediaan sumber pendukungnya. Peringkatan didasarkan pada lima kategori yakni: perpustakaan, surat kabar, input dan output pendidikan, serta ketersediaan komputer.

Kualitas literasi perlu dukungan kekuatan, baik sektor sosial, ekonomi, maupun pemerintahan melalui pendekatan konsep multidimensi (Arifin, 2016). Tergerusnya kesadaran akan budaya literasi karena adanya gadget sebagai sarana instan untuk mengetahui fenomena yang ada di sekitarnya, menguatkan bahwa budaya literasi tidak didukung dengan kemampuan menghasilkan seni karya untuk membangun karakter bangsa yang kuat. Kurangnya pengetahuan mengakibatkan kesulitan dalam menulis suatu karya tulis/ilmiah, karena tidak terbiasanya menulis atau membaca suatu bacaan tertentu. Lemahnya kemampuan tersebut dipengaruhi oleh kurangnya penguasaan keterampilan menulis (Sholeh, 2016; Trimantara, 2005) sebagai akibat kosa kata yang dimiliki sangat minim (Satini, 2014).

Permasalahan yang ditemukan saat ini adalah lemahnya literasi atau pemahaman terhadap karya tulis seperti esai dan karya ilmiah lainnya di Angkatan Muda Muhammadiyah (AMM) yang ada di Kota Parepare. Salah satu parameter adalah kurangnya karya cipta (baik seni atau karya ilmiah) yang menjadi buah-tangan AMM Kota Parepare. Sebagai organisasi kepemudaan, Angkatan Muda Muhammadiyah (AMM) bertanggungjawab dalam mewujudkan terciptanya Kader Bangsa, Kader Ummat dan 
Kader Persyarikatan yang memiliki wawasan intelektual dan berkompeten.

Budaya kritis perlu dibangun agar angkatan muda yang ada dapat berkembang dan menjadi pencerah untuk generasi berikutnya.Hal ini menjadibukti bahwa Kota Parepare tidak ikut terjebak sebagai dampak dari keberadaan pengaruh penyebaran globalisasi teknologi, maka dipandang penting untuk merekontruksi budaya literasi saat ini.Oleh kerana itu, kegiatan ini bertujuan untuk mewujudkan dan meningkatkan kesadaran terhadap budaya literasi serta menghasilkan karya tulis melalui pelatihan penulisan esai bagi Angkatan Muda Muhamamdiyah (AMM) se Kota Parepare.

\section{METODE}

Mitra pengabdian adalah Angkatan Muda Muhammadiyah yang ada di Kota Parepare, terdiri dari Ikatan Pelajar Muhammadiyah (IPM), Ikatan Mahasiswa Muhahammadiyah (IMM) dan Pemuda Muhamamdiyah (PM) se Kota Parepare. Jumlah peserta dalam kegiatan ini sebanyak 45 orang yang terdiri dari pengurus Pimpinan Daerah Ikatan Pelajar Muhammadiyah Kota Parepare, Pimpinan Cabang Ikatan Mahasiswa Muhammadiyah Kota Parepare dan Pimpinan Daerah Pemuda Muhammadiyah Kota Parepare.

Mitra IPM meliputi pelajar Sekolah Menengah Atas (SMA) dan Sekolah Menengah Kejuruan (SMK) Muhamamdiyah Kota Parepare (13 orang), sedangkan mitra IMM (21 orang) adalah mahasiswa yang ada di Kota Parepare. Untuk mitra Pemuda Muhammadiyah (11 orang) terdiri dari guru dan dosen yang ada di Kota Parepare. Kegiatan pengabdian kepada masyarakat ini terpusat di ruangan pertemuan SMK Muhammadiyah Kota Parepare (Sulawesi Selatan).

Kegiatan pengabdian mengacu pada pola kolaboratif intensif dengan melakukan Focus Group Discussion (FGD) antara perwakilan masing-masing ortom sebagai mitra,serta melibatkan pakar dan praktisi yang tergabung dalam kepengurusan Pimpinan Daerah Pemuda Muhammadiyah Kota Parepare. Pelaksanaan mengikuti tahapan yaitu persiapan, pelaksanaan, evaluasi dan pendampingan, sebagai berikut:
1. Tahapan persiapan, dilakukan dengan observasi untuk menentukan materi pelatihan berdasarkan permasalahan dan kebutuhan mitra. Strategi yang dilakukan adalah melakukan sosialisasi untuk menemukan peserta yang memiliki minat terhadap karya tulis.

2. Tahap pelaksanaan kegiatan dilakukan dengan intensif workshop yang terdiri dari pemaparan materi/ceramah dan diikuti dengan diskusi berdasarkan permasalahan yang timbul pada mitra. Pada proses pelaksanaan kegiatan pengabdian dilakukan dengan pendekatan metode ceramah, diskusi dan pelatihan (workshop). Pelaksanaan kegiatan melibatkan narasumber yang terdiri dari akademisi dan praktisi gerakan literasi yang ada di Kota Parepare. Metode ceramah digunakan untuk memberikan wawasan umum terhadap pentingnya literasi, meliputi esai, puisi dan cerpen serta literasi digital. Metode diskusi digunakan untuk memberikan peluang kepada mitra sebagai peserta untuk bertanya dan selanjutnya akan ditanggapi oleh narasumber. Metode pelatihan. digunakan untuk mempraktekkan teknis dan cara membuat karya tulis berupa esai atau karya ilmiah lainnya.

3. Tahap evaluasi dan pendampingan, bertujuan untuk mengukur kemampuan dalam menulis ide pemikiran atau gagasan yang bersifat membangun. Selanjutnya, mitra yang belum mampu menggali potensi menulisnya akan dilakukan pendampingan hingga mampu menarasikan ide atau gagasan mereka tentang opini yang ingin mereka tuang menjadi karya tulis.

Seluruh rangkaian pembelajaran dalam program pengabdian ini menggunakan pendekatan partisipasi aktif peserta. Mitra tidak hanya cukup mendengarkan, mencatat, kemudian menghafal materi, melainkan peserta harus aktif berfikir, berkomunikasi, mencari dan mengolah berbagai sumber bacaan untuk menjadi suatu karya tulis. Program pengabdian ini tetap mengedepankan kaidah ilmiah dan empiris untuk mencapai tujuan dari program pengabdian literasi menulis tersebut. 


\section{HASIL DAN PEMBAHASAN}

Hasil dari kesepakatan yang dihasilkan secara bersama melalui Focus Group Discussion (FGD) serta observasi, maka materi hasil observasi adalah pelatihan menulis yang mengarah pada karya tulis yang bersifat umum, yaitu cara membuat/menulis naskah esai. Hasil kesepakatan ini secara bersama diwakilkan dari Organisasi Angkatan Muda Muhamamdiyah (AMM) se Kota Parepare. Perwakilan tersebut terdiri dari Pimpinan Daerah Ikatan Pemuda Muhammadiyah Kota, Pimpinan Cabang Ikatan Mahasiswa Muhammadiyah Kota Parepare dan PareparePimpinan Daerah Pemuda Muhammadiyah Kota Parepare.

Berdasarkan observasi bersama maka tema kegiatan yaitu "Bergembira, Bergerak Bersama Kader Memajukan Bangsa". Rumusan ini menghasilkan materi yang meliputi teknik menulis esai. Tujuan dari penulisan esai tersebut untuk menghasilkan pemuda Kota Parepare yang mampu menuang opini mereka menjadi sebuah karya tulis.

Kegiatan pengabdian ini berlangsung selama 3 (tiga) hari yang berjalan dengan lancar dan efektif. Mitra sebagai peserta diikuti sebanyak 45 orang peserta dari berbagai Organsiasi Otonom (Ortom) Muhammadiyah yang ada di Kota Parepare, yaitu Pemuda Muhammadiyah, Ikatan Mahasiswa Muhammadiyah dan Ikatan Pelajar Muhammadiyah. Pencapaianjumlah peserta yang dihasilkan merupakan komunikasi intens yang dilakukan antara pimpinan Ortom yang ada. Menurut Mansyur \& Akidah (2018), terbangunnya komunikasi sejak awal yang efektif dan efisien dapat mewujudkan ketercapaian target kegiatan.Ini menunjukkan adanya kegelisahan yang memicu mereka untuk menjadi penulis seperti buku kegemaran mereka, dan kegiatan ini sebagai wadah untuk pemenuhan aspirasi mereka.

Peserta pelatihan berpartisipasi aktif untuk menggalakkan gemar membaca. Permasalahan-permasalahan dalam membuat karya tulis diuraikan berdasarkan kecenderungan mereka dalam menuangkan ide ke dalam bentuk tulisan, namun kemampuan argumentasi mereka cukup tinggi. Untuk memenuhi penguasan materi maka setiap sesi materi yang selesai kemudian diulas kembali masalah-masalah yang disertai diskusi sebagai strategi solusi tersebut. Menurut Karim (2014), motivasi dalam pembelajaran dapat terbangun dengan adanya partisipasi aktif peserta.

Narasumber mengajak peserta secara aktif berpartisipasi untuk merangsang kemampuan menulis peserta. Kemampuan membangun imajinasi dalam menulis esai sangat dipengaruhi oleh penguasaan materi dan forum oleh narasumber sehingga proses pembelajaran dan pelatihan berjalan aktif. Mengajak peserta untuk aktif dalam suatu pembelajaran adalah bentuk dari strategi active learning (Zahira, 2013).

Dari 45 peserta, dihasilkan 15 naskah esai, selebihnya peserta memilih untuk membuat naskah lainnya. Naskah lain yang dimaksud adalah puisi dan cerita pendek. Sedangkan 15 naskah esai menuang topik yang beragam dan disesuaikan dengan kemampuan narasi peserta berdasarkan topik bacaan yang mereka senangi.

Sebagai hasil kegiatan adalah terkumpulnya naskah-nsakah yang telah diserahkan. Naskah atau artikel selanjutnya dikaji dan dibedah bersama serta mengarahkan konsep untuk menghasilkan tulisan esai yang dapat mempengaruhi publik (pembaca). Termasuk susunan paragraf, penggunaan bahasa dalam membuat narasi tulisan. Secara garis besar, kompetensi menulis peserta beragam, hal ini dikarenakan peserta memiliki bidang keilmuan dan sumber bacaan yang beragam juga.

Peserta dalam membuat naskah/artikel masih menggunakan gaya bahasa keseharian, isi naskah seakan-akan berbicara tentang kehidupan sehari-hari dan tidak memiliki tujuan akhir dari penulisan esai tersebut. Menurut Maryam (2007), bahwa Esai adalah salah satu jenis tulisan yang dapat dijadikan sarana berkomunikasi dengan publik, selain itu juga bahwa penggunaan bahasa saat berkomunikasi terjadi internalisasi kaidah yang mengatur penggunaan bahasa suatu tulisan.

Monitoring dan evaluasi dilakukan 3 (tiga) hari setelah kegiatan pelatihan dilakukan. Hasil monev adalah tersedianya beberapa artikel yang diserahkan oleh peserta kegiatan. Namun masih terdapat beberapa naskah/artikel yang dianggap perlu dilakukan pendampingan. 
Adapun materi naskah yang layak untuk dipublikasikan terdiri dari 15 judul, yaitu:

1) Walau beda, kembalilah kepada Muhammadiyah;

2) Hak rakyat terhadap alam;

3) Kemajuan Muhammadiyah: tanggungjawab kita;

4) Memuliakan tamu;

5) Dakwah yang mencerahkan;

6) Meneropong masa depan pemuda;

7) Kaum buruh dalam kemasan elit politik: idolatri gaya baru;

8) BerMuhammadiyah itu;

9) Minat baca, perpustakaan dan masa depan literasi kota;

10) Dunia yang berubah;

11) Seruan kader, mari berdakwah;

12) Perempuan dalam pandangan Al-qur'an;

13) Pesisir laut ku;

14) Korupsi: sebuah penyakit akut dan berbahaya;

15) Kita bineka kawan.

Sebagai keberlanjutan proses pendampingan maka dilanjutkan dengan publikasi. Publikasi dilakukan dengan melibatkan penerbit yang ada di Kota Parepare, yaitu UMPAR Press sebagai salah satu penerbit perguruan tinggi yang ada. Buku telah diterbitkan dengan judul "Kembali Kepada Muhammadiyah" (Gambar 2). Adapun alasan pemilihan tema ini didasari dengan melihat keragaman isi dan didasari oleh pernyataan $\mathrm{KH}$. Ahmad Dahlan, yaitu:

"Muhammadiyah ini lain dengan Muhammadiyah yang akan datang. Makateruslah kamu bersekolah, menuntut ilmu pengetahuan dimana saja. Jadilah guru,kembali pada Muhammadiyah. Jadilah dokter, kembali kepada Muhammadiyah. Jadilah Master, insinyur dan lain-lain, dankembalilah kepada Muhammadiyah." KH. Ahmad Dahlan.

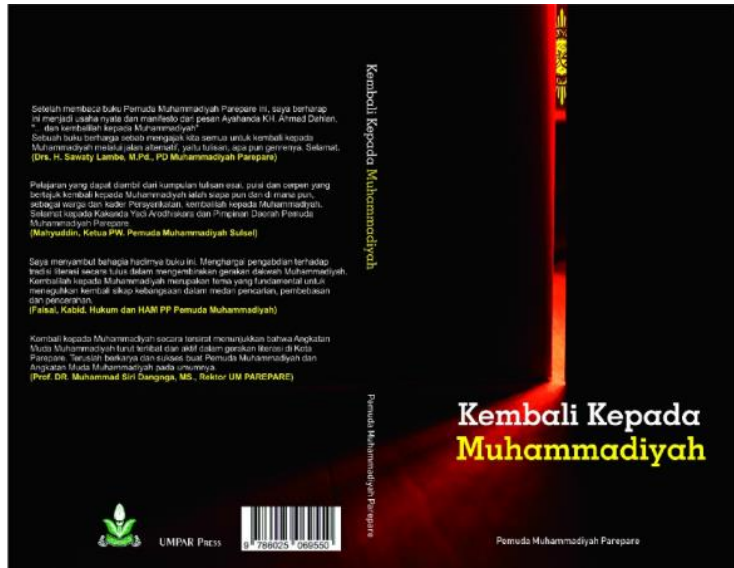

Gambar 1. Cover buku

\section{SIMPULAN}

Kegiatan pelatihan penulisan esai dilakukan selama 3 (tiga) hari dan berjalan dengan lancar dan efektif. Materi kegiatan dirancang berdasarkan hasil observasi dan Focus Group Discussion (FGD), yaitu terfokus kepada pelatihan penulisan esai. Tugas pertama naskah esai peserta menunjukkan lemahnya pengetahuan dalam menulis karya tulis esai.Pemateri dan steering commitee selanjutnya memberi pemahaman dalam menulis naskah esai yang baik dan benar. Hasil evaluasi dihasilkan 16 naskah esai yang layak dipublikasikan, dan publikasi dikerjasamakan dengan penerbit perguruan tinggi yaitu UMPAR Press. Untuk keberlanjutan program dibentuk taman pustaka sebagai wadah tempat berkumpulnya pegiat literasi buku di Kota Parepare.

\section{DAFTAR PUSTAKA}

Akdiana, F. (2017). Dialog Buku di Dalam Kelas.

https://www.kompasiana.com/46times 159de482c3f8bf444b27dff12/dialogbuku-di-dalam-kelas.

Arifin, A. S. (2016). Kecenderungan Global Pendidikan Tinggi dan Pergeseran Paradigma Reformasi Pendididikan Tinggi pada Institusi Pendidikan Tinggi Keagamaan Islam. LITERASI (Jurnal Ilmu Pendidikan), 6(2), 135154. 
Daniel, G., (2006). Social Intelligence: The New Science of Human Relationships, New York : Bantam Books

Junia, A. V., Sofah, R., \& Putri, R. M. (2019). Tingkat Prokrastinasi Akademik Berdasarkan Intensitas Penggunaan Media Sosial Di SMP Negeri 18 Palembang. Jurnal Konseling Komprehensif: Kajian Teori dan Praktik Bimbingan dan Konseling, 6(1), 21-29.

Karim, D. (2014). Pengaruh Pembelajaran Model Partisipatif, Aktif, Kreatif, Efektif dan Menyenangkan (Pakem) Terhadap Efektivitas Pembelajaran Teknik Dasar Service Bolavoli (Study pada Siswa Kelas X di SMK PGRI 1 Jombang). Jurnal Pendidikan Olahraga dan Kesehatan, 2(2).

Maftuh, B. (2010). Memperkuat Peran IPS dalam Membelajarkan Keterampilan Sosial dan Resolusi Konflik. Pidato pengukuhan jabatan guru besar dalam bidang pendidikan ilmu pengetahuan sosial pada Fakultas Pendidikan Ilmu Pengetahuan Sosial Universitas Pendidikan Indonesia.

Mansyur, U., \& Akidah, I. (2018). Peningkatan Kompetensi Profesional Guru Mts DDI Padanglampe Kabupaten Pangkep Melalui Pelatihan Penulisan Karya Tulis Ilmiah. JPPM (Jurnal Pengabdian dan Pemberdayaan Masyarakat), 2(2), 273-278.

Manumpil, B., Ismanto, A. Y., \& Onibala, F. (2015). Hubungan penggunaan gadget dengan tingkat prestasi siswa di SMA Negeri 9 Manado. Jurnal Keperawatan, $3(2)$.

Maryam, S. (2007). Pengembangan Kreativitas Berbahasa dalam Menulis Esai. Educationist, 1(2), 103-115.

Mulyati, T., \& Frieda, N. R. H. (2019). Kecanduan Smartphone Ditinjau Dari Kontrol Diri dan Jenis Kelamin pada Siswa SMA Mardisiswa Semarang. Empati, 7(4), 152-161.

Satini, R. (2014). Hubungan Minat Baca dan Motivasi Belajar dengan Keterampilan Menulis Berita Siswa Kelas VIII SMP Negeri 24 Padang. Bahasa, Sastra, dan Pembelajaran, 2(1).

Sholeh, K. (2016). Teknik Mind Mapping Sebagai Upaya Untuk Meningkatkan Keterampilan Menulis Cerpen Pada Siswa SMA, Jurnal Pendidikan Surya Edukasi (JPSE), 2 (2), 26-45

Trimantara, P., (2005). Metode sugestiimajinasi dalam pembelajaran menulis dengan media lagu. Jurnal Pendidikan Penabur, 5(4), 1-15.

Zahira, H. (2013). Pengaruh Pengunaan Strategi Belajar Aktif Tipe Everyone Is A Teacher Here (ETH) Terhadap Kemampuan Berpikir Kritis Matematika Siswa SMA Muhammadiyah 1 Pekanbaru. Disertasi, Universitas Islam Negeri Sultan Syarif Kasim Riau. 